\title{
KINERJA GURU DALAM MENINGKATKAN PROSES PEMBELAJARAN PADA MIN MESJIDRAYA BAITURRAHMANBANDA ACEH
}

\author{
Rika Dewi ${ }^{1}$ \\ Akbid Saleha Banda Aceh. \\ Email korespondensi: rikadewi1983@gmail.com.
}

\begin{abstract}
ABSTRAK
Kinerja guru dalam proses pembelajaran adalah hasil kerja seorang guru, baik secara kualitas maupun kuantitas dalam melaksanakan tugas sesuai dengan tanggung jawab dan wewenangnya berdasarkan standar kinerja yang telah ditetapkan. Tujuan penelitian adalah untuk mengetahui: kemampuan dan ketepatan, kualitas, inisiatif, dan kendala guru dalam meningkatkan proses pembelajaran pada MIN Mesjid Raya Baiturrahman Banda Aceh. Penelitian ini menggunakan pendekatan kualitatif. Teknik pengumpulan data melalui wawancara, observasi, dan dokumentasi. Subjek dalam penelitian ini adalah Kepala Sekolah, Guru, dan Siswa. Hasil penelitian menunjukkan bahwa: 1) Kemampuan guru-guru dalam membuat RPP di sekolah sudah ada, sebagaimana terlihat saat melakukan proses pembelajaran guru merasa tidak bingung dan kesulitan lagi, karena semua bahan ajar sudah disiapkan, sesuai dengan kompetensi yang dirumuskan secara jelas dan konkrit. Namun demikian, proses pembelajaran belum sepenuhnya sukses, karena masih ada sebahagian guru yang belum tepat menggunakan RPP pada saat proses pembelajaran berlangsung; (2) Kualitas dan inisiatif guru dalam proses pembelajaran terlihat masih masih belum baik, seperti Rencana Pelaksanaa Pembelajaran (RPP) yang dibuat oleh guru belum semuanya berkualitas, kemudian guru kurang memiliki keterampilan bertanya dengan pertanyaan terbuka terhadap siswa, dimana pertanyaan yang sering diberikan guru adalah pertanyaan tertutup, karena kurangnya menguasai bahan ajar yang lebih luas. Kondisi ini membuat sebahagian siswa kurang dapat mengembangkan daya pikir, imajinasi dan analisis yang tinggi dalam belajar, sehingga dilihat dari peningkatan prestasi belajar siswa belum mengalami peningkatan yang signifikan, karena guru hanya mempersiapkan semua tuntutan proses pembelajaran; dan (3) Kendala yang ditemui kepala sekolah dalam meningkatkan kinerja guru antara lain: kurang tersedianya dana untuk pelatihan guru di luar jam dinas, masih ada sebagian kecil guru kurang aktif dan hasil penataran belum mampu mengimbas kepada temannya, guru juga masih kurang dalam penguasaan landasan kependidikan, sehingga hal ini berdampak terhadap peningkatan kinerja dalam melaksanakan pembelajaran.
\end{abstract}

Kata Kunci: Kinerja Guru, Proses Pembelajaran, dan MIN Mesjid Raya

\section{PENDAHULUAN}

Peningkatan mutu pendidikan ditentukan oleh kesiapan sumber daya manusia yang terlibat dalam proses pendidikan. Guru merupakan salah satu faktor penentu tinggi rendahnya mutu pendidikan. Guru merupakan sumber daya 
manusia yang menjadi perencana, pelaku, dan penentu tercapainya tujuan pendidikan. Usman (2012: 6) mengemukakan bahwa asumsi tentang guru adalah:

(1) Agen perubahan; (2) Berperan sebagai fasilitator yang memungkinkan terciptanya suatu kondisi yang baik terhadap peserta didik untuk belajar dengan penuh semangat; (3) Mampu bertanggung jawab atas terciptanya hasil belajar pada subjek didik; (4) Menjadi contoh terhadap subjek didik; (5) Dapat bertanggung jawab secara profesional dalam meningkatkan kemampuannya; dan (6) menjunjung tinggi kode etik profesionalnya.

Dengan demikian, maka kinerja guru akan dapat ditingkatkan, jika guru mampu menjalankan berbagai peran di atas, terutama sebagai agen perubahan, bertanggung jawab serta dapat menjunjung tinggi kode etik profesionalnya dalam melaksanakan tugas dan fungsinya.

Kinerja guru Sekolah Dasar yang baik dapat terlihat pada kemampuan merencanakan, melaksanakan, dan menilai proses belajar mengajar yang intensitasnya dilandasi etos kerja dan disiplin profesional guru. Kinerja yang baik dapat dipengaruhi oleh kemampuan dan motivasi yang ada pada seseorang. Kemampuan merupakan hasil perpaduan antara pendidikan, pelatihan, dan pengalaman. Motivasi adalah suatu daya pendorong yang menyebabkan seseorang berbuat atau melakukan sesuatu.

Kenyataan di MIN Mesjid Raya Baiturrahman Banda Aceh, proses pembelajaran yang dilakukan oleh guru belum maksimal sesuai dengan yang diharapkan. Guru sudah membuat Rencana Pelaksanaan Pembelajaran (RPP), tetapi dalam pelaksanaan guru masih banyak yang mengajar tanpa menggunakan RPP. Masih ada guru yang tidak pernah menggunakan media sebagai alat bantu dalam mengajar. Guru belum memiliki kemampuan mendalam dalam menerapkan model-model pembelajaran kooperatif, seperti jigsaw, Number Head Together, snowball throwing, group investigation, atau model kooperatif lainnya yang sesuai diterapkan untuk materi dan mata pelajaran tertentu.

Sehubungan dengan pentingnya proses pembelajaran yang berkualitas, maka penulis ingin melakukan penelitian dengan judul: "Kinerja Guru dalam Meningkatkan Proses Pembelajaran pada MIN Mesjid Raya Baiturrahman Banda Aceh."

\section{KAJIAN KEPUSTAKAAN}

Kinerja merefleksikan kesuksesan suatu organisasi, maka dipandang penting untuk mengukur karakteristik tenaga kerjanya. Kinerja merupakan kegiatan yang dijalankan oleh tiap-tiap individu dalam kaitannya untuk mencapai tujuan yang sudah direncanakan. Uno (2012:70) menjelaskan bahwa "Kinerja adalah gambaran tentang hasil kerja seseorang berkaitan dengan tugas yang dilaksanakan, dan didasarkan pada tanggung jawab profesional yang dimiliki seseorang". Artinya, hasil kerja yang dicapai oleh seorang guru dalam melaksanakan tugas yang dibebankan kepadanya. Kinerja merupakan suatu proses tentang bagaimana pekerjaan berlangsung untuk mencapai hasil kerja, namun hasil pekerjaan itu sendiri juga menunjukkan kinerja. 
Indikator kinerja juga menganjurkan sudut pandang prospektif (harapan ke depan) dari pada retrospektif (melihat ke belakang). Hal ini menunjukkan jalan pada aspek kinerja yang perlu diobservasi. Uno (2012: 71) bahwa cakupan wilayah kinerja atas lima dimensi dan indikator yaitu:Kualitas kerja yaitu mencakup bagaimana menguasai bahan, mengelola proses pembelajaran, dan mengelola kelas.

(1)Kecepatan/ketepatan yaitu menggunakan media atau sumber belajar, menguasai landasan pendidikan, merencanakan program pengajaran.

(2)Inisiatif dalam kerja yaitu memimpin kelas, mengelola interaksi pembelajaran, dan melakukan penilaian hasil belajar siswa.

(3)Kemampuan yaitu menggunakan metode dalam pembelajaran, memahami dan melaksanakan fungsinya dan layanan bimbingan penyuluhan.

(4)Komunikasi yaitu memahami dan menyelenggarakan administrasi sekolah, memahami dan dapat menafsirkan hasil-hasil penelitian untuk peningkatan kualitas pembelajaran.

Berdasarkan kutipan di atas, dapat disimpulkan bahwa bagi guru sekolah dasar berdasarkan dimensi kinerja yang berkaitan dengan tugas mereka adalah tugas rutin sebagai guru yang berkewajiban melakukan tugas pembelajaran di satu sisi, sedangkan di sisi lain guru Sekolah Dasar dituntut untuk mampu melakukan perencanaan, pengelolaan, dan pengadministrasian atas tugas-tugas pembelajaran tersebut. Guru merupakan pendidik di sekolah yang bertugas mengajarkan siswasiswanya sehingga memperoleh berbagai pengetahuan, keterampilan, nilai dan sikap yang sesuai dengan harkat dan martabat manusia.

Kinerja guru Sekolah Dasar dapat terefleksi dalam tugasnya sebagai seorang pengajar dan sebagai seorang pelaksana administrator kegiatan mengajarnya. Tujuan kinerja adalah menyesuaikan harapan individual dengan tujuan organisasi. Kesesuaian antara upaya pencapaian tujuan individu dengan tujuan organisasi akan mampu mewujudkan kinerja yang baik.

Kinerja guru dapat dilihat dan diukur berdasarkan spesifikasi atau kriteria kompetensi yang harus dimiliki oleh setiap guru. Berkaitan dengan kinerja guru, wujud perilaku yang dimaksud adalah kegiatan guru dalam proses pembelajaran. Wahyudi (2012:7) mengemukakan bahwa "Kinerja guru adalah prestasi yang diperlihatkan dalam bentuk perilaku". Kinerja erat hubungannya dengan masalah produktivitas, karena merupakan indikator dalam menentukan bagaimana untuk menentukan produktivitas yang tinggi dalam suatu organisasi.

Berdasarkan uraian di atas, dapat diketahui bahwa kinerja guru adalah hasil kerja, baik secara kualitas maupun kuantitas yang dicapai oleh guru dalam melaksanakan tugasnya sesuai dengan tanggung jawab dan fungsinya masingmasing.

Kinerja guru adalah kinerja sekolah dan mutu guru menentukan mutu pendidikan pada semua jenis dan jenjang pendidikan, karena itu guru senantiasa dituntut untuk tanggap terhadap perubahan yang terjadi dalam masyarakat sebagai dampak sistem informasi dan perkembangan ilmu pengetahuan. Sejalan dengan itu guru harus berusaha untuk mengembangkan kinerjanya secara mandiri maupun secara kelompok. Sebagaimana telah dikatakan bahwa pengembangan kinerja 
guru dapat dilaksanakan sendiri oleh guru bersangkutan melalui berbagai kegiatan dalam melaksanakan tugasnya.

Di sisi lain, guru berada di bawah kepemimpinan kepala sekolah, maka kepala sekolah secara lansung berkewajiban untuk mengembangkan kinerja guru melalui cara yang sudah lazim di sekolah. Pembinaan guru pada dasarnya berkaitan dengan fungsi dan usaha-usaha untuk meningkatkan pengetahuan, keterampilan, dan kepribadian guru sebagai pengajar, pendidik, dan pembimbing.

Manajemen kinerja menjadi faktor yang sangat strategis dalam upaya untuk terus meningkatkan kinerja guru sebagai sumber daya manusia sesuai dengan tuntutan perubahan, Wibowo (2012:9) mengemukakan bahwa:

Manajemen kinerja merupakan gaya manajemen dalam mengelola sumber daya yang berorientasi pada kinerja yang melakukan proses komunikasi secara terbuka dan berkelanjutan dengan menciptakan visi bersama dan pendekatan strategis serta sebagai kekuatan pendorong untuk mencapai tujuan organisasi

Dapat disimpulkan bahwa manajemen kinerja merupakan suatu proses yang dapat mendorong personil untuk meningkatkan kinerjanya baik kinerja individu, tim, maupun organisasi kearah yang lebih baik dan berkualitas.

Manajemen kinerja menduduki posisi strategis dalam suatu organisasi termasuk sekolah, upaya untuk terus meningkatkan kemampuan dan kinerja organisasi dalam menghadapi tuntutan dan tantangan yang datang dari dalam maupun dari luar, hal ini sangat ditentukan oleh bagaimana organisasi mengelola kinerjanya dalam melaksanakan perannya dalam masyarakat. Kedudukan penting dari manajemen kinerja tersebut disebabkan oleh tujuan yang secara spesifik untuk meningkatkan atau memperbaiki pencapain tujuan, pengetahuan, keterampilan dan kompetensi, personil yang mampu meningkatkan keefektifan kinerja sehari-hari.

Secara teoritis manajemen kinerja merupakan suatu proses sistematis, terdiri dari langkah-langkah mencakup perencanaan kinerja, review dan diskusi kinerja, evaluasi kinerja dan tindakan adaptif dan korektif untuk mengembangkan strategi dalam mengatasi berbagai kinerja. Lebih jauh, Wibowo (2012: 22) mengemukakan bahwa:

Proses manajemen kinerja adalah melakukan pendekatan yang bersifat menyeluruh (holistik) untuk mengelola kinerja yang memadai menjadi kepentingan organisasi, karena manajemen kinerja bersangkutan dengan masalah pengelolaan semua sumber daya dalam organisasi yang menjadi masukan, proses pelaksanaan kinerja, hasil kinerja, dan manfaat serta dampak dari suatu kinerja

Berdasarkan pendapat di atas, dapat digambarkan bahwa majanemen kinerja mencakup suatu proses pelaksanaan kinerja, bagaimana dijalankan oleh pihak yang bersangkutan. Jadi manajemen kinerja merupakan suatu proses melakukan perbaikan secara berkelanjutan atas kinerja. Secara umum kegiatan atau usaha-usaha yang dapat dilakukan oleh kepala sekolah untuk meningkatkan kinerja guru sesuai dengan fungsinya sebagai supervisor. 
Pembelajaran menuntut keaktifan guru dan siswa, karena yang mengajar adalah guru dan yang belajar adalah siswa yang berorientasi pada materi pengembangan pengetahuan, sikap dan keterampilan siswa sebagai sasaran belajar. Pembelajaran atau pengajaran menurut Uno (2012: 2) menjelaskan bahwa: "Upaya untuk membelajarkan siswa". Pengertian ini secara implisit dalam pengajaran terdapat kegiatan memilih, menetapkan, mengembangkan metode untuk mencapai hasil pengajaran yang diinginkan. Pemilihan, penetapan, dan pengembangan metode ini didasarkan pada kondisi pengajaran yang ada.Kegiatan mengajar diharapkan mampu memperluas wawasan pengetahuan, meningkatkan ketrampilan dan menumbuhkan sejumlah sikap positif yang direfleksikan siswa melalui cara berfikir dan bertindak sebagai dampak hasil belajarnya. Hal yang harus diperhatikan untuk mencapai tujuan tersebut adalah bagaiamana cara mengorganisasikan pembelajaran, bagaimana menyampaikan isi pembelajaran, dan bagaimana menata interaksi antara sumber-sumber belajar yang ada agar dapat berfungsi secara optimal. Sehubungan dengan itu, Suryosubroto (2010: 48) mengelompokkan tugas guru dalam proses pembelajaran kedalam tiga kegiatan yaitu:

1. Merencanakan program pengajaran, seperti program tahunan, program semester, program mingguan, program satuan pelajaran, rencana pelaksanaan pembelajaran.

2. Menyajikan dan melaksanakan pengajaran, seperti menyampaikan materi, menggunakan metode mengajar, menggunakan media, sumber belajar, mengelola kelas.

3. Melaksanakan evaluasi, seperti menganalisis hasil evaluasi belajar, melaporkan hasil evaluasi belajar, dan melaksanakan program perbaikan dan pengayaan.

Penyusunan rencana pembelajaran merupakan langkah persiapan yang dilakukan guru sebelum melakukan proses pembelajaran di kelas. Perencanaan yang baik merupakan langkah penting yang akan menentukan keberhasilan proses pembelajaran. Sementara itu langkah pelaksanaan pembelajaran merupakan implementasi rencana pembelajaran dalam konteks interaksi pembelajaran di kelas. Sementara evaluasi dilakukan untuk mengetahui bagaimana hasil pembelajaran, apakah telah sesuai dengan yang direncanakan atau belum.

Kepala Sekolah dapat diartikan sebagai tenaga fungsional guru yang diberikan tugas tambahan untuk memimpin suatu sekolah, sehingga terjadinya interaksi antara guru yang memberikan pelajaran dan siswa yang menerima pelajaran. Kepala sekolah bertanggung jawab atas manajemen pendidikan yang secara langsung berkaitan dengan proses pembelajaran di sekolah. Sebagaimana dikemukakan dalam Pidarta (2009: 13) dalam melaksanakan tugas sehari-hari kepala sekolah mempunyai lima macam peran yakni: “(1) Kepala sekolah sebagai manajer; (2) Sebagai administrator; (3) Penghubung dengan masyarakat; (4) Sebagai Pemimpin; dan (5) Supervisor".

Guru sangat berperan dalam membantu perkembangan peserta didik untuk mewujudkan tujuan hidupnya secara optimal. Tugas guru dapat disebut sebagai pendidik dan penanggung jawab dalam pendisiplinan peserta didik, agar tingkah 
laku peserta didik tidak menyimpang dengan norma-norma yang ada. Guru mempunyai tugas dan kewajiban, tidak hanya mengajar, mendidik dan membimbing siswa tetapi juga patut sebagai model dalam pembelajaran sehingga mampu menciptakan suasana belajar yang aktif dan menyenangkan yang lebih dikenal dengan Pembelajaran PAKEM. Sehubungan dengan tugas guru Uzer (Uno, 2010:20) mengemukakan tiga jenis tugas guru yaitu:

1) Tugas guru dalam bidang profesi, yaitu tugas guru dalam mengembangkan nilai hidup, mengembangkan iptek, mengembangkan keterampilan siswa.

2) Tugas guru dalam bidang kemanusiaan, yaitu tugas guru untuk menjadi orang tua kedua, memahami peserta didiknya, membantu peserta didik menstranformasikan dirinya sebagai upaya pembentukan sikap.

3) Tugas guru dalam bidang kemasyarakatan yaitu guru berkewajiban mencerdaskan bangsa Indonesia seluruhnya berdasarkan pancasila.

Peserta didik yang duduk di jenjang pendidikan dasar dan menengah disebut siswa. Seorang siswa mempunyai tugas utama yaitu belajar. Belajar merupakan proses perubahan dari tidak tahu menjadi tahu, atau dari tidak bisa menjadi bisa. Menurut Undang-Undang Nomor 20 Tahun 2003 tentang Sistem Pendidikan Nasional (UU Sisdiknas, 2013:3) menjelaskan bahwa: "Peserta didik adalah anggota masyarakat yang berusaha mengembangkan potensi diri melalui proses pembelajaran yang tersedia pada jalur, jenjang, dan jenis pendidikan tertentu".

\section{METODE PENELITIAN PENELITIAN \\ Pendekatan Penelitian}

Pendekatan penelitian ini menggunakan metode penelitian kualitatif yaitu metode penelitian yang mendeskripsikan kondisi subjek penelitian pada saat penelitian dilaksanakan. Mulyana (Satori dan Komariah, 2010: 23) mengemukakan bahwa: "Pendekatan kualitatif cenderung mengarah pada penelitian yang bersifat naturalistik fenomenologis dan penelitian etnografi. Karenanya, seringkali penelitian kualitatif dipertukarkan dengan penelitian naturalistik dan etnografi dalam penelitian".

\section{Subjek Penelitian}

Subjek penelitian adalah: kepala sekolah, guru, dan siswa pada MIN Mesjid Raya Banda Aceh Banda Aceh.

\section{Teknik Pengumpulan Data}

Teknik pengumpulan data dilakukan melalui wawancara, observasi, dan studi dokumentasi.

\section{Teknik Analisis Data}

Analisis data merupakan proses sistematis pencarian dan pengaturan deskripsi wawancara, catatan lapangan. Menurut Miles dan Humberman (Emzir, 
2010: 129) ada tiga analisis data yang dilaksanakan adalah: reduksi data, penyajian data dan penarikan kesimpulan.

\section{HASIL DAN PEMBAHASAN \\ Kemampuan dan Ketepatan Guru dalam Meningkatkan Proses Pembelajaran pada MIN Mesjid Raya Baiturrahman Banda Aceh}

Kemampuan dan ketepatan guru dalam merencanakan pembelajaran merupakan faktor yang sangat menentukan keberhasilan prestasi peserta didik yang baik. Namun, kemampuan merencanakan pembelajaran saja tidak cukup tanpa didukung oleh kemampuan guru yang mapan dan tepat dalam melaksanakan pembelajaran dengan efektif, sehingga pembelajaran menjadi lebih baik yang dapat dilihat dari berhasilnya peserta didik mencapai prestasi.

Merencanakan pembelajaran tidak bisa terlepas dari variabel pembelajaran. Hal ini disebabkan oleh perencanaan pembelajaran tersebut dengan empat variabel pembelajaran yang menjadi titik perhatian ilmuwan pembelajaran yang diungkapkan oleh Uno (2012: 15) yaitu:1) kondisi pembelajaran, 2) bidang studi, 3) strategi pembelajaran, dan 4) hasil pembelajaran. Variabel yang dikelompokkan ke dalam kondisi pembelajaran adalah karakteristik siswa, karakteristik lingkungan pembelajaran, dan tujuan institusional.

Kemampuan sebahagian guru-guru MIN Mesjid Raya Baiturrahman Banda Aceh dalam merencanakan pembelajaran sudah baik, namun ketepatan menggunakan metode belajar yang efektif masih kurang, keterampilan bertanya kurang bervariatif, sehingga siswa dalam belajar terkadang membosankan. Namun sebahagian lagi guru sudah membuat RPP dengan baik dan tepat, sehingga siswa menjadi lebih menyenangkan dalam belajar.

Proses pembelajaran yang dilaksanakan dapat dikatakan belum dapat meningkatkan kinerja guru yang baik, karena tidak didukung oleh profesional yang mapan atau dengan kata lain belum dapat disebut sebagai guru yang profesional. Guru yang profesional adalah guru yang memiliki seperangkat kompetensi (pengetahuan, keterampilan, dan perilaku) yang harus dimiliki, dihayati, dan dikuasai oleh guru dalam melaksanakan tugas keprofesionalannya.

\section{Kualitas dan Inisiatif Guru dalam Meningkatkan Proses Pembelajaran pada MIN Mesjid Raya Baiturrahman Banda Aceh}

Guru-guru MIN Mesjid Raya Baiturrahman Banda Aceh sudah memiliki kualitas kerja yang baik, hal ini terlihat dari guru mampu menguasai bahan ajar, mengelola kelas, guru juga sudah mampu merencanakan pembelajaran dan menggunakan media belajar yang baik, namun belum sepenuhnya di gunakan dalam proses pembelajaran, mereka terkadang hanya mengajar tanpa menggunakan rencana pelaksanaan pembelajaran (RPP), mereka mengganggap itu tidak penting karena tanpa RPP pembelajaran juga akan berjalan dengan sukses. Terkecuali pada saat supervisi datang itu baru digunakan oleh semua guru.

Guru-guru mempersiapkan silabus yang disusun dengan baik, rencana pelaksanaan pembelajaran dan pelaksanaan pembelajaran itu sendiri dilaksanakan 
dengan penuh tanggung jawab, inisiatif guru terlihat dari guru dapat mengelola kelas dengan menyenangkan, dan menguasai bahan ajar dengan baik. Namun, itu semua hanya sebahagian guru yang mampu melakukan hal tersebut, sedangkan bagi sebahagian guru belum mampu melaksanakan pembelajaran dengan profesional, pelaksanaan pembelajarandilakukan guru lebih sekedar rutinitas yang setiap hari dijalankan, padahal untuk perencanaan sudah dilakukan tapi untuk pelaksanaan belum dijalankan seoptimal mungkin.

Kondisi di atas, mengindikasikan bahwa kepala sekolah mengatur setiap guru yang memiliki kualitas dan inisiatif serta pengetahuan yang lebih akan diberikan tanggung jawab untuk menjadi guru kelas VI, untuk mendapatkan prestasi peserta didik yang lebih baik.

Guru MIN Mesjid Raya Baiturrahman Banda Aceh dalam melaksanakan pembelajaran sudah menunjukkan kondisi yang baik, namun belum untuk semua guru. Sebahagian guru melaksanakan pembelajaran dengan begitu matang dan sesuai dengan apa yang telah direncanakan, Namun bagi sebahagian guru MIN Mesjid Raya Baiturrahman Banda Aceh yang kurang memiliki inisiatif dalam meningkatkan kinerja, maka mereka akan melaksanakan pembelajaran sebagai kewajiban dan rutinitas mereka bekerja. Artinya, bagi mereka melaksanakan pembelajaran tanpa mempersoalkan bagaimana hasil belajar siswa.

Meningkatnya kualitas sumber daya manusia (SDM) akan termanifestasikan dalam kinerja SDM dalam melaksanakan tugas dan peran yang diembannya sesuai dengan tuntutan organsasi. Bacal (Wibowo, 2012: 8) mengemukakan bahwa: "Manajemen kinerja adalah sebagai sebuah proses komunikasi yang dilakukan secara terus menerus dalam kemitraan antara karyawan dengan atasan langsungnya". Proses komunikasi ini meliputi kegiatan membangun harapan yang jelas serta pemahaman mengenai pekerjaan yang akan dilakukan. Proses komunikasi merupakan suatu sistem, memiliki sejumlah bagian yang semuanya harus diikutsertakan, apabila manajemen kinerja ini hendak memberikan nilai tambah bagi organisasi, manajer, dan karyawan. Hal ini yang sedang dilakukan oleh kepala sekolah dan pengawas agar sekolah memiliki manajemen kinerja yang baik, sehingga akan memberi hasil yang terbaik juga bagi sekolah, guru dan yang lainnya.

Dalam pelaksanaan pembelajaran guru-guru MIN Mesjid Raya Baiturrahman Banda Aceh harus memahami prinsip-prinsip umum belajar mengajar, guru harus mengajar dengan berbagai inisiatif berdasarkan pengalaman dan dapat merubah menjadi lebih baik dari pengalaman masa lalu, pengetahuan dan keterampilan yang diajarkan harus bersifat praktis, dalam mengajar guru harus memahami perbedaan individual peserta didik, kesiapan guru dan peserta didik dalam belajar sangat penting dan tujuan pengajaran harus diketahui peserta didik serta belajar harus menggunakan prinsip psikologis. Jika guru mengajar tidak memahami prinsip-prinsip ini maka proses pembelajaran akan berhasil dan guru dapat meningkatkan kinerja guru dengan baik. Namun, hal tersebut belum semua guru memahami masih ada guru yang mengajar tidak menggunakan prinsip-prinsip tersebut, guru mengajar hanya sebatas tanggung jawab mereka dalam pekerjaan. 
Berpedoman pada prinsip di atas, maka kinerja guru dapat dilihat dari salah satu kemampuan guru dalam melaksanakan pembelajaran sesuai waktu dan kegiatan yang telah direncanakan. Seorang guru dituntut harus professional artinya, guru harus memiliki sejumlah kemampuan sebagai seorang profesional. Seorang penyandang profesi dapat disebut profesional ketika kompetensi sudah menjadi bagian integral dari kehidupannya.

\section{Kendala Kinerja Guru dalam Meningkatkan Proses Pembelajaran pada MIN Mesjid Raya Baiturrahman Banda Aceh}

Beberapa kendala yang ditemukan kepala sekolah dalam peningkatan kinerja guru diantaranya; guru masih kurang dalam penguasaan landasan kependidikan dan pelaksanaan program peningkatan kinerja, kurangnya tersedianya dana untuk pelatihan guru di luar jam dinas, masih ada sebagian kecil guru tidak aktif dan hasil penataran belum mampu mengimbas kepada temannya. Hal ini memberi gambaran bahwa sebagian kecil guru pada MIN Mesjid Raya Baiturrahman Banda Aceh belum mampu dalam penguasaan landasan kependidikan, sehingga berdampak terhadap kinerjanya dalam melaksanakan pembelajaran. Guru-guru yang tidak mampu dalam menguasai landasan kependidikan, akan mengalami kendala dalam mengajar dan membimbing siswa.

Kinerja seseorang tidak dipengaruhi oleh beberapa faktor. Suragih (Wahyudi, 2012: 87) mengemukakan beberapa karakteristik biografi yang dapat mempengaruhi kinerja:

a. Umur. Kinerja seseorang akan menurun seiring dengan bertambahnya umur. Dalam kenyataannya kekuatan kerja seseorang akan menurun dengan bertambahnya usia.

b. Jenis kelamin. Wanita lebih suka menyesuaikan diri dengan wewenang, sedangkan pria lebih agresif dalam mewujudkan harapan dan keberhasilan.

c. Jabatan/senioritas. Kedudukan seseorang dalam organisasi akan dapat mempengaruhi kinerja yang dihasilkan, karena perbedaan jabatan akan membedakan jenis kebutuhan yang ingin mereka puaskan dalam pekerjaan individu yang bersangkutan.

Kendala yang terdapat pada guru, bahwa guru tidak ada keinginan untuk menyusun program, mereka hanya menggunakan program tahun lalu dengan sedikit direvisi. Kendala yang dihadapai kepala sekolah adalah tidak mampu memeriksa dengan baik, program-program yang dibuat oleh sejumlah guru dan hampir tidak ada waktu untuk itu. Hal ini, memberi gambaran bahwa peningkatan kinerja guru belum terlaksana dengan baik.

Kepala sekolah menemui hambatan dalam mengimplementasikan program-program yang telah disusun, khususnya program yang menyangkut dengan peningkatan kinerja guru.

Hambatan lain yang dialami adalah kepala sekolah tidak ada waktu untuk melakukan supervisi guru-guru dalam kegiatan perbaikan dan pembinaan dalam meningkatkan kinerja guru. Penyebab tidak ada waktu bagi kepala sekolah, karena waktu lebih banyak digunakan untuk tugas-tugas lain yaitu rapat dinas, masalah keuangan, dan program kerja sekolah dengan komite sekolah/ orang tua murid. 
Tugas kepala sekolah melakukan supervisi guru-guru dilimpahkan kepada wakil kepala sekolah dan guru-guru senior.

\section{KESIMPULAN DAN SARAN}

\section{Kesimpulan}

Kemampuan dan ketepatan guru-guru MIN Mesjid Raya Baiturrahman Banda Aceh dalam membuat Rencana Pelaksanaan Pembelajaran (RPP) di sekolah sudah ada, sebagaimana terlihat saat melakukan proses pembelajaran guru merasa tidak bingung dan kesulitan lagi, karena semua bahan ajar sudahdisiapkan sesuai dengan kompetensi yang dirumuskan secara jelas dan konkrit namun demikian, proses pembelajaran belum sepenuhnya sukses, karena masih ada sebahagian guru yang belum tepat menggunakan RPP pada saat proses pembelajaran berlangsung.

Kualitas dan inisiatif guru-guru MIN Mesjid Raya Baiturrahman Banda Aceh dalam pelaksanaan pembelajaran sesuai dengan program yang sudah disusun guru masih kurang memiliki keterampilan bertanya dengan pertanyaan terbuka terhadap siswa dengan baik, dimana pertanyaan yang sering diberikan guru masih dalam pertanyaan tertutup, karena kurangnya menguasai bahan ajar yang lebih luas. Umumnya guru hanya mempersiapkan semua tuntutan untuk melaksanakan pembelajaran sebagai rutinitas, sehingga kualitas pembelajaran tergolong masih cukup secara keseluruhan.

Hambatan yang ditemui kepala sekolah dalam meningkatkan kinerja guru antara lain; kurangnya waktu memeriksa Rencana Pelaksanaan Pembelajaran (RPP) dengan baik, kurang tersedianya dana untuk pelatihan guru di luar jam dinas, masih ada sebagian kecil guru tidak aktif dan hasil penataran belum mampu mengimbas kepada temannya. Sebagian kecil guru pada MIN Mesjid Raya yang belum mampu dalam penguasaan landasan kependidikan, sehingga berdampak terhadap kinerjanya dalam melaksanakan pembelajaran.

\section{Saran}

Disarankan kepada Pengawas Pendidikan dan Kepala Sekolah MIN Mesjid Raya Baiturrahman Banda Aceh untuk memberikan pelatihan dalam membuat perencanaan proses pembelajaran dengan lebih baik lagi kepada tenaga pendidik, sehingga semua terlatih dan profesional untuk melakukan kegiatan tersebut, guru juga perlu memahami kewajiban apa saja yang harus dipersiapkan sebelum pembelajaran dimulai.

Diharapkan kepada para guru untuk dapat terus memperkaya pengetahuan terutama terkait dengan bidang keahlian masing-masing dalam proses pembelajaran. Para guru harus memiliki strategi tertentu dalam pembelajaran agar hasil belajar menjadi lebih berkualitas. Misalnya, guru melakukan pembelajaran perbaikan dengan lebih banyak memberikan tugas-tugas tambahan bagi siswa yang belum mecapai ketuntasan belajar.

Diharapkan kepada Kepala Sekolah dapat memberikan pelatihan teman sebaya (peer coaching) kepada guru-guru MIN Mesjid Raya Baiturrahman Banda Aceh, agar mereka mampu meningkatkan kinerja dalam proses pembelajaran 
perbaikan. Pelatihan teman sebaya yang dimotori oleh salah seorang guru pemandu ternyata dapat memotivasi para guru dalam merencanakan, melaksanakan dan mengevaluasi pembelajaran dengan baik. Melalui pelatihan teman sebaya (peer coaching) guru akan dapat meningkatkan kompetensi dan memilih metode-metode yang tepat dalam melaksanakan pembelajaran. Dengan demikian, pelatihan teman sebaya (peer coaching) perlu dilakukan dan dilestarikan oleh sekolah-sekolah.

\section{DAFTAR PUSTAKA}

\section{BUKU}

Emzir. (2010). Metode Penelitian Kualitatif Analisis Data. Jakarta: Raja Grafindo Persada.

Pidarta, Made. (2009) Supervisi Pendidikan Kontekstual. Jakarta: Rineka Cipta.

Satori, Djama'an dan Komariah, Aan (2010). Metodelogi Penelitian Kualitatif. Bandung: Alfabeta.

Suryosubroto. (2010). Manajemen Pendidikan Di Sekolah. Jakarta: Rineka Cipta Uno, Hamzah. (2012). Teori Kinerja dan Pengukurannya. Jakarta: Bumi Aksara. (2012). Perencanaan Pembelajaran. Jakarta: Bumi Aksara.

Usman, Nasir. (2012). Manajemen Peningkatan Kinerja Guru. Bandung: Cita Pustaka Media Perintis.

Wahyudi, I. (2012). Mengejar Profesionalisme Guru, Strategi Praktis Mewujudkan Citra Guru Profesional. Jakarta: Prestasi Pustaka.

Wibowo. (2012). Manajemen Kinerja. Jakarta: Raja Grafindo Persada.

Undang-Undang

Undang-Undang(2011) Sistem Pendidikan Nasional (UU RI. Nomor 20 Tahun 2003). Jakarta: Sinar Grafika.

Undang-Undang Nomor 14 Tahun 2005, tentang Guru dan Dosen. Sinar Grafika. 